Article

\title{
Impact of the Framework Type on the Regeneration of Coked Zeolites by Non-Thermal Plasma in a Fixed Bed Dielectric Barrier Reactor
}

\author{
Amir Astafan, Alexander Sachse, Catherine Batiot-Dupeyrat ${ }^{\mathbb{D}}$ and Ludovic Pinard * \\ Institut de Chimie des Milieux et Matériaux de Poitiers, UMR 7285 CNRS, 4 Rue Michel Brunet, Bâtiment B27, \\ 86073 Poitiers CEDEX9, France; amir.astafan@univ-poitiers.fr (A.A.); alexander.sachse@univ-poitiers.fr (A.S.); \\ catherine.batiot.dupeyrat@univ-poitiers.fr (C.B.-D.) \\ * Correspondence: Ludovic.pinard@univ-poitiers.fr; Tel.: +33-54-945-3905
}

Received: 4 November 2019; Accepted: 21 November 2019; Published: 24 November 2019

check for updates

\begin{abstract}
The formation of coke as a result of propene transformation at $623 \mathrm{~K}$ on zeolites results from a product shape selectivity mechanism of which the products are polyaromatic molecules, such as pyrene on MFI, anthracene on MOR, pyrene and coronene on FAU. Zeolite regeneration can be achieved by using non-thermal plasma (NTP), with decreased energy consumption, employing a fixed bed dielectric barrier reactor. The efficiency of this alternative regeneration process depends on the coke toxicity. On MFI and FAU (featuring three-dimensional 10 and 12 ring channel systems, respectively) coking occurs by poisoning the Brønsted acid sites; on MOR, (presenting a one-dimensional 12 ring channel system) pore blocking takes place, leading to higher coke toxicity. A complete coke removal is achieved on MFI and FAU zeolites using NTP within $3 \mathrm{~h}$, while for MOR coke, removal proceeds slower and is incomplete after $3 \mathrm{~h}$ on stream. Hence, the efficiency of regeneration is impacted by the accessibility of active oxygenated species generated under plasma (e.g., $\mathrm{O}^{*}, \mathrm{O}_{2}{ }^{+}$) to coke molecules.
\end{abstract}

Keywords: coke regeneration; zeolite; non-thermal plasma; oxidation

\section{Introduction}

The main cause of acidic zeolite deactivation is carbon deposition (coke), which poisons or blocks the accessibility of reactants to active sites [1]. Such deactivation and the associated regeneration of catalysts represent a major financial burden and important environmental costs for industrial processes.

Coke formation results from numerous transformations of reactants and/or products by consecutive condensation-polymerization-dehydrogenation reactions. The chemical composition of coke depends on the reaction conditions (temperature, contact time and time-on-stream) [1-5] and on the aging treatment [6,7]. These factors noticeably affect its chemical nature, and thus, the $\mathrm{H} / \mathrm{C}$ ratio of the coke molecules. For example, the $\mathrm{H} / \mathrm{C}$ coke ratio retained within zeolite micropore reaches a value of almost 0.8-1.0 for reaction temperatures higher than $523 \mathrm{~K}$ [1]; while a subsequent aging treatment with inert gas leads to a decrease of the $\mathrm{H} / \mathrm{C}$ ratio down to 0.5 [8]. Coked catalysts can be rejuvenated by hydrogen treatment (partial elimination of coke [9]) and totally or partially regenerated by burning-off [1,7,8,10-14] and oxygen pulsing combustion [15], respectively.

The coke trapped in micropores begins to be oxidized from temperatures $\left(\mathrm{T}_{\mathrm{ox}}\right)$ higher than $600 \mathrm{~K}$, while complete regeneration requires $\mathrm{T}_{\mathrm{ox}}$ above $800 \mathrm{~K}$ [15]. $\mathrm{T}_{\mathrm{ox}}$ is independent of the coke content; [16] yet is importantly impacted by the zeolite structure $[16,17]$. This latter observation can be rationalized on diffusional restrictions of combustion gases and on the location $[18,19]$ and nature $[7,8,19,20]$ of the coke.

The impact of zeolite framework was studied by Magnoux et al. [16] based on three protonic zeolites: $\mathrm{FAU}(\mathrm{Si} / \mathrm{Al}=3.0), \mathrm{MOR}(\mathrm{Si} / \mathrm{Al}=7.7)$ and $\mathrm{MFI}(\mathrm{Si} / \mathrm{Al}=46)$. While for both large pore zeolites 
(FAU and MOR) no differences were found, coke oxidation was revealed to be significantly slower on the medium pore sample (MFI), which was ascribed to a diffusional effect. Novasoka et al. [17] further evidenced that carbonaceous deposits on MFI $(\mathrm{Si} / \mathrm{Al}=13.5)$ are oxidized at higher temperatures compared to those on FAU $(\mathrm{Si} / \mathrm{Al}=2.5)$ despite their less condensed nature. Yet, it seems more probable that the slower coke oxidation on MFI can be ascribed to the much lower concentration of protonic sites, which impact the evolution of labile oxygenate compounds in the combustion mechanism. Indeed, it was inferred that the concentration of protonic sites had a significant effect on the coke oxidation. As such, a higher proton concentration leads to faster coke oxidation [21]. Contrarily, the extra framework aluminum (EFAL) species (which can lead to the generation of Lewis acid sites) does not impact the oxidation rate [22].

It was evidenced that the kinetic order of the combustion of coke with respect to oxygen is lower than one [22,23], which indicates that the first stages of the coke combustion proceed with the participation of the coke radical centers [21,22].

The regeneration at high temperature can lead to irreversible damage of the zeolite structure through dealumination, which leads to the formation of EFAL species and defect sites, hence, impacting acidic and textural properties. To reduce structural damage, one solution is the reduction of $T_{o x}$, which can be achieved by (i) increasing the oxygen content during the process, [1] (ii) adding a few ppm of transition metals (e.g., $\mathrm{Pt}, \mathrm{Fe}, \mathrm{Ni}, \mathrm{Co}, \mathrm{V}$ ) and/or [10] (iii) tuning the textural properties of the zeolite [24-27]. Indeed, as far as the latter is concerned, improved accessibility of oxygen to coke proved to allow to reduce $\mathrm{T}_{\text {ox }}$ by more than $150 \mathrm{~K}$ by using of hierarchical zeolites [24].

The off-site regeneration (OSR) of spent catalysts is often economically more interesting than using fresh catalysts. OSR is further supported by industry due to safety regulations and time issues, and furthermore, allows the development of eco-friendly and energetic efficient processes. We have recently shown that coke combustion assisted by non-thermal plasma (NTP) is a valuable alternative to classical thermal treatments; allowing for total regeneration of zeolite catalysts at room temperature [28-31]. Contrary to the classical regeneration process, NTP is sensitive to the nature of the coke molecules [28]; hence, its efficiency should further depend on the zeolite framework.

Thus, the aim of this paper is to study the impact of the zeolite framework on the coke removal by non-thermal plasma, generated in a fixed bed dielectric barrier reactor. For this purpose, three zeolite structures, featuring similar concentration of Brønsted acid sites, were used, namely, FAU, MOR and MFI.

\section{Results}

\subsection{Properties and Characterization of the FAU, MOR and MFI Zeolites}

Table 1 summarizes the main framework characteristics of MOR, FAU and MFI zeolites, their acid and textural properties. FAU and MOR are large pore zeolites with a pore aperture constituted of $12 \mathrm{~T}$ atoms ( $\mathrm{Si}$ or $\mathrm{Al})$ and MFI is a medium pore zeolite with $10 \mathrm{~T}$ atoms.

Table 1. Textural and acidic properties of commercial zeolites: MOR, FAU and MFI.

\begin{tabular}{|c|c|c|c|c|c|c|}
\hline Catalyst & Pore Aperture & Si/Al & $\mathrm{V}_{\text {micro }}{ }^{a}$ & $\mathrm{~V}_{\text {meso }}{ }^{a}$ & {$\left[\mathrm{PyH}^{+}\right]^{\mathbf{b}}$} & [PyL $^{c}$ \\
\hline & & $\mathrm{mol} / \mathrm{mol}$ & $\mathrm{cm}^{3} \mathrm{~g}^{-1}$ & $\mathrm{~cm}^{3} \mathrm{~g}^{-1}$ & $\mu \mathrm{mol} \mathrm{g}{ }^{-1}$ & $\mu \mathrm{mol} \mathrm{g}^{-1}$ \\
\hline MOR & $126.5 \times 7.0 * \leftrightarrow 82.6 \times 5.7 *$ & 38 & 0.20 & 0.08 & 254 & 35 \\
\hline FAU & $127.4 \times 7.4^{* * *}$, supercage $\varnothing 12 \AA$ & 17 & 0.30 & 0.15 & 271 & 101 \\
\hline MFI & $\left\{10\left(5.1 \times 5.5^{*} \leftrightarrow 105.3 \times 5.6\right\}^{* * *}\right.$ & 40 & 0.17 & 0.07 & 304 & 44 \\
\hline
\end{tabular}

(a) microporous volume using t-plot method; mesoporous volume $=V_{\text {total }}-V_{\text {micro }}\left(V_{\text {total }}\right.$ : determined from the adsorbed volume at $\mathrm{p} / \mathrm{p} 0=0.9),(\mathrm{b}, \mathrm{c})$ : Concentrations of Brønsted $\left(\left[\mathrm{PyH}^{+}\right]\right)$and Lewis $([\mathrm{PyL}])$ sites able to retain pyridine at $423 \mathrm{~K}$.

Contrary to MFI and FAU zeolites $\left(^{* * *}\right)$, MOR is considered as a one dimensional channel system $\left.{ }^{*}\right)$, owing to the small size of its secondary pore system $(82.6 \times 5.7)$. The FAU zeolite $(127.4 \times 7.4)$, 
which features large inner cavities of $12 \AA$ and MFI $\left(\{105.3 \times 5.6 \leftrightarrow 105.1 \times 5.5\}^{* * *}\right)$, presents channel intersections that lead to cage-like voids with a diameter of $7 \AA$ (see Supplementary Materials).

The microporous volume, which can be considered as a fingerprint of the zeolite framework amounts to $0.30,0.20$ and $0.17 \mathrm{~g} \cdot \mathrm{cm}^{-3}$ for FAU, MOR and MFI, respectively, as expected (See Supplementary Materials, Figure S1) The commercial zeolites used in this study feature a large intracrystalline mesoporosity $\left(0.07\right.$ to $0.15 \mathrm{~cm}^{3} \cdot \mathrm{g}^{-1}$, corresponding to a pore size distribution of $4 \mathrm{~nm}<\varnothing<7 \mathrm{~nm}$, which results from the steaming process performed by the supplier. Moreover, gas phase dealumination yields to the formation and accumulation of extra framework aluminum (EFAL) species in the porosity, of which some feature Lewis acidy $\left(35-101 \mu \mathrm{mol} \mathrm{g}^{-1}\right.$, Table 1$)$. The concentration of Brønsted acid sites probed by pyridine amounts to similar values for all of the studied zeolites and is comprised between 250 and $300 \mu^{m o l ~ g}{ }^{-1}$ (Table 1).

The total number of aluminum sites corresponds to the sum of the concentration of the Brønsted acid sites (BAS) and twice that of the Lewis acid sites (LAS), assuming that the LAS predominantly consist out of $\mathrm{Al} 2 \mathrm{O} 3$ species. In the case of the MFI zeolite, the theoretical acidity calculated from the global Si/Al ratio $\left(\left[\mathrm{H}^{+}\right]_{\text {theoritical }}=400 \mu \mathrm{mol} . \mathrm{g}^{-1}\right)$ is almost identical to that probed by pyridine $\left(392 \mu \mathrm{mol} . \mathrm{g}^{-1}\right)$. Yet, for the MOR and FAU a discrepancy of $20 \%$ and $50 \%$ between theoretical and probed acidity was observed. This difference is no related to the lack of accessibility of the pyridine to the acid sites as all the bridged $\mathrm{OH}$ groups are neutralized after the addition of the probe (see Supplementary Materials). The observed difference indicates that not all of the EFAL species feature acidic properties.

\subsection{Coke Characterization and Toxicity on the FAU, MOR and MFI Zeolites}

The conversion of propene on the three zeolites at $623 \mathrm{~K}$ for $12 \mathrm{~h}$ yields to different coke contents, despite almost identical BAS concentration. Therefore, the amount of trapped coke depends on shape, size and connectivity of the zeolite micropores. The highest coke content (14.4 wt.\%) is obtained on the FAU zeolite, which features a large inner cavity. Almost four times less coke is formed on the medium pore zeolite with interconnected channels. Indeed MFI is known as coke resistant zeolite [1]. In MFI, the limited void space around the active sites, combined with high connectivity between them, both prevent the growth of coke and favor desorption of coke precursors, which further limits its growth. However, in the case of zeolite featuring inner cavities (e.g., FAU) or mono-dimensional pores (e.g., MOR), the growth of coke is promoted. On zeolites with three-dimensional 12 or 10 membered ring-channel systems (i.e., FAU and MFI), the coke partially poisons the BAS (Scheme 1), which decreases the microporous volume (Vmicro) to a certain extent. As expected, the decrease of Vmicro and BAS is more important for FAU than for MFI.

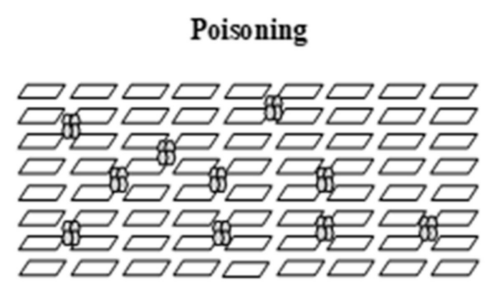

MFI

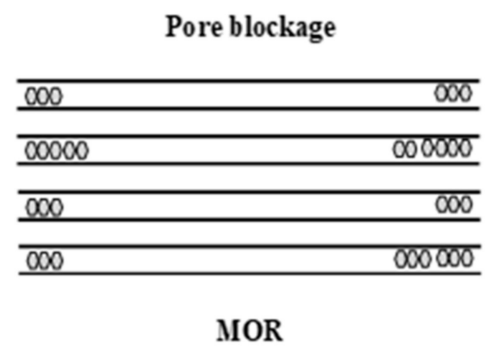

Scheme 1. Coking mode on MFI and MOR.

On the zeolite featuring the mono-dimensional channel system, i.e., MOR, the coke entirely blocks the access to the microporous volume, hence, deactivating all BAS located in the zeolite channels (Table 2). Indeed, a single coke molecule at the pore mouth renders all the acidic sites located along the channel inactive, [1,32,33]; hence, coke toxicity is highest (Scheme 1). 
Table 2. Textural and acidic properties of coked commercial zeolites: MOR, FAU and MFI.

\begin{tabular}{cccccc}
\hline Catalyst & $\% \mathbf{C}^{\mathbf{a}}$ & $\mathrm{V}_{\text {micro }}{ }^{\mathbf{b}}$ & $\mathbf{V}_{\text {meso }}{ }^{\mathbf{b}}$ & {$\left[\mathbf{P}_{\mathbf{y}} \mathbf{H}^{+}\right]^{\mathbf{c}}$} & {$[\mathbf{P y L}]^{\mathbf{c}}$} \\
\hline MOR & $\mathbf{w t .} \%$ & $\mathbf{c m}^{\mathbf{3}} \mathbf{g}^{\mathbf{- 1}}$ & $\mathbf{c m}^{\mathbf{3}} \mathbf{g}^{\mathbf{- 1}}$ & $\mu \mathbf{m o l ~ \mathbf { g } ^ { \mathbf { 1 } }}$ & $\mu \mathbf{m o l ~ \mathbf { g } ^ { \mathbf { 1 } }}$ \\
\hline FAU & 10.3 & 0.00 & 0.06 & 0 & 0 \\
MFI & 14.4 & 0.10 & 0.12 & 25 & 42 \\
\hline
\end{tabular}

(a) Elemental analysis, (b) microporous volume using t-plot method; mesoporous volume $=\mathrm{V}_{\text {total }}-\mathrm{V}_{\text {micro }}\left(\mathrm{V}_{\text {total }}\right.$ : determined from the adsorbed volume at $\left.\mathrm{p} / \mathrm{p}_{0}=0.9\right)$. (c) Concentrations of Brønsted $\left(\left[\mathrm{PyH}^{+}\right]\right)$and Lewis $([\mathrm{PyL}])$ sites able to retain pyridine at $423 \mathrm{~K}$.

The total pore blocking further affects regeneration by combustion with air. Indeed, the temperature of coke oxidation is $50 \mathrm{~K}$ higher for the MOR zeolite than for the two others (Table 3). Mesoporous volume remains almost constant for all zeolites upon coking, indicating that coke is mainly trapped in the micropores (Table 2). Table 3 reports for the three zeolites the coke distribution and composition. The coke located on the external surface $\left(\mathrm{C}_{\text {external }}\right)$ is extracted by a simple washing with methylene chloride, while coke trapped within the micropores is recovered by zeolite framework mineralization followed by a liquid-liquid extraction with dichloromethane. Most of released coke molecules are soluble in $\mathrm{CH}_{2} \mathrm{Cl}_{2}\left(\mathrm{C}_{\text {soluble }}\right)$. The proportion of the insoluble fraction $\left(\mathrm{C}_{\text {insoluble }}\right)$ increases with growing coke content, which is yet limited to $20 \%$ on the FAU zeolite.

Table 3. Main properties of the coke molecules on MOR, FAU and MFI zeolites (NAR: number of aromatic rings), and initial rate of coke elimination under NTP.

\begin{tabular}{|c|c|c|c|c|c|c|c|}
\hline \multirow{2}{*}{ Catalyst } & \multicolumn{3}{|c|}{ Coke } & \multirow{2}{*}{$\begin{array}{r}T_{\text {ox }}{ }^{c} \\
(K)\end{array}$} & \multicolumn{2}{|c|}{ NAR } & \multirow{2}{*}{$\begin{array}{c}\begin{array}{c}\text { Initial } \\
\text { Oxidation Rate }\end{array} \\
\begin{array}{c}\mathrm{g}_{\text {coke } \text { min }^{-1}}(\times 1000) \\
\end{array}\end{array}$} \\
\hline & $\begin{array}{c}\text { External a }^{\text {a }} \\
\text { wt. } \%\end{array}$ & $\begin{array}{c}\text { Soluble }{ }^{b} \\
\text { wt. } \%\end{array}$ & $\begin{array}{c}\text { Insoluble } \\
\text { wt. } \%\end{array}$ & & $\begin{array}{c}\leq 2 \\
\text { wt. } \%\end{array}$ & $\begin{array}{c}\geq 3 \\
\text { wt. } \%\end{array}$ & \\
\hline MOR & 1.1 & 8.3 & 0.9 & 848 & 2.6 & 6.8 & 1.5 \\
\hline FAU & 0.7 & 10.9 & 2.8 & 798 & 7.4 & 5.9 & 1.0 \\
\hline MFI & 0.6 & 3.3 & 0.1 & 798 & 1.5 & 1.8 & 1.5 \\
\hline
\end{tabular}

(a) Extracted by washing with $\mathrm{CH}_{2} \mathrm{Cl}_{2}$, (b) after digestion of the zeolite framework, (c) TGA.

The GC-MS analysis indicates that the $\mathrm{C}_{\text {soluble }}$ is mainly composed of aromatic compounds, which can be lumped together according to the number of aromatic rings (NAR). It partially consists of coke "precursors" (alkylbenzenes and alkylnaphthalenes), and polycyclic compounds (NAR $\geq 3$ ) featuring an aromatic backbone that depends on the zeolite framework, which was identified to be anthracene for MOR, pyrene for MFI, and pyrene and coronene for FAU.

\subsection{Kinetic of Coke Removal by a NTP}

The coke removal is achieved without external heating employing a DBD fixed bed plasma reactor and a low deposited power (12 $\mathrm{W}$ of input power). Figure 1 compares the percentage of removed coke and the $\mathrm{CO}$ and $\mathrm{CO}_{2}$ yield observed for the three zeolites as function of time.

For the FAU zeolite, the coke removal rate is slow $\left(r_{c}=1.010^{-3} \mathrm{~g}_{\mathrm{c}} \cdot \mathrm{min}^{-1}\right.$, Table 3) and features a change in selectivity. For the zeolite with the highest amount of coke precursors, i.e., FAU (Table 2), VOCs (or the default of the carbon balance) are apparent after $60 \mathrm{~min}$. For MOR, which features a more important proportion of polyaromatic compounds (Table 3), the carbon unbalance appears after 90 min, while for the MFI, zeolite VOCs appear almost immediately. 

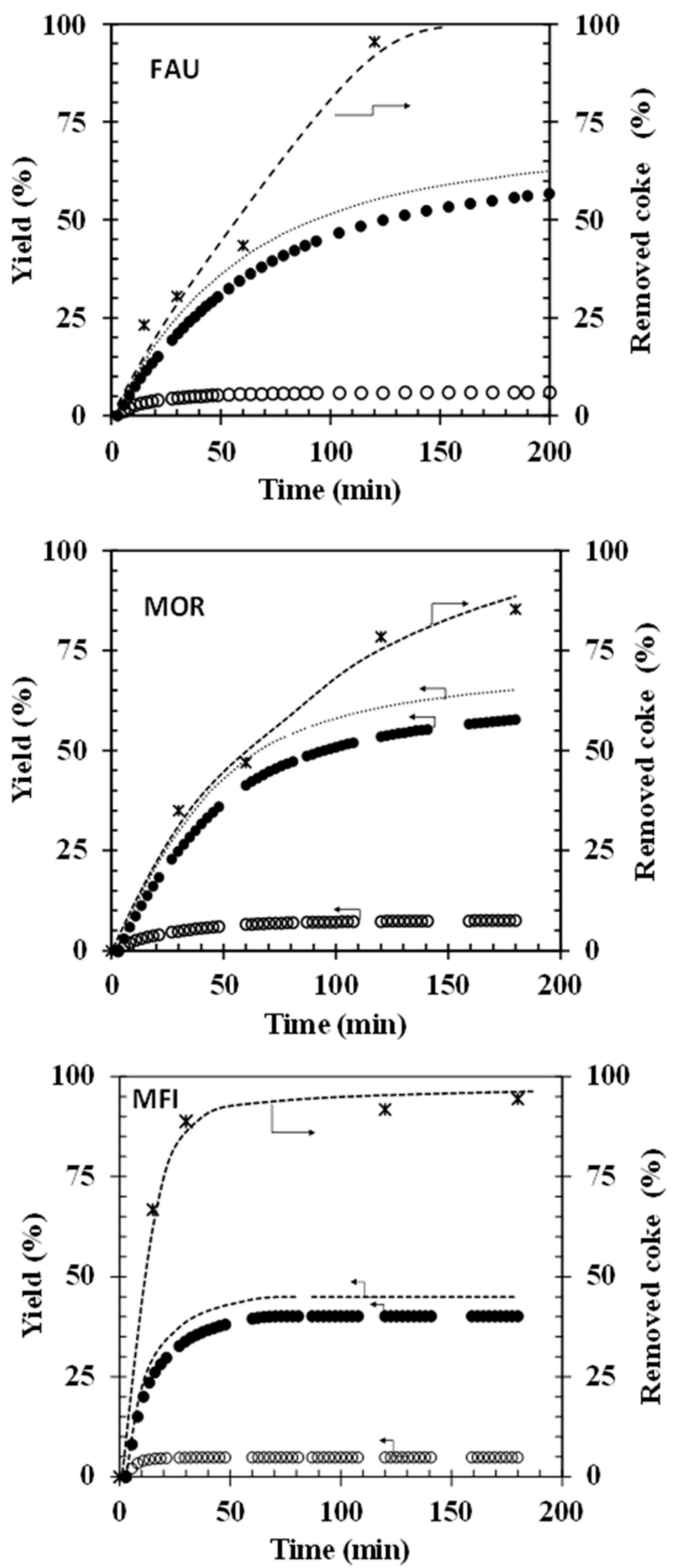

Figure 1. Removed coke determined by elemental analysis $\left(^{*}\right)$ and $\mathrm{CO}_{2}(\bullet), \mathrm{CO}(\bigcirc)$ yield and sum of yields (-) for FAU, MOR and MFI zeolites as a function of the regeneration time for $12 \mathrm{~W}$ at $293 \mathrm{~K}$.

Hence, these results unambiguously prove that oxidation selectivity under plasma discharge strongly depends on the nature of coke. A high coke polycyclic compound character leads to lower $\mathrm{CO}_{2}$ selectivity. In a previous study, we have indeed shown that active oxygenated species oxidize alkylbenzene 36 times faster than alkylpyrene [31]. The dissociation energies of covalent bonds in coke molecules are $3.7 \mathrm{eV}$ for $\mathrm{C}-\mathrm{H}$ in the methyl group, $4.3 \mathrm{eV}$ for $\mathrm{C}-\mathrm{H}$ of aromatic rings, 5.0 to $5.3 \mathrm{eV}$ for $\mathrm{C}-\mathrm{C}$ of methyl group connected with aromatic ring and $5.5 \mathrm{eV}$ for $\mathrm{C}=\mathrm{C}$ in aromatic rings [34]. As the average energy of electrons generated in a NTP discharge ranges from 1 to $10 \mathrm{eV}$, the oxidation by 
accelerated electrons and active oxygenated species, will strongly depend on the $\mathrm{C} / \mathrm{H}$ molar ratio of the coke molecules. This means that coke combustion begins by the oxidation of the methyl/ethyl groups which decompose into $\mathrm{CO}_{2}$, while the dealkylated aromatic rings are partially oxidized.

Figure 2 presents the evolution of recovered microporous volume as a function of the treatment time. Microporous volume is fully restored for MFI after only $15 \mathrm{~min}$ of treatment. For FAU initial microporosity is achieved after more than $120 \mathrm{~min}$. On the tridimensional porous zeolites, microporous volume increases almost linearly with time, while on the mono-dimensional MOR, a different behavior is observed. Here, linear micropore recovery was observed within the first hour of plasma treatment, which then remained almost constant during the second hour of treatment, while coke was still being eliminated (decreasing from 5 to $2 \mathrm{wt} . \%$ ). The microporous volume increased again after $120 \mathrm{~min}$, yet even after $3 \mathrm{~h} \mathrm{10 \%}$ of microporosity, still remained inaccessible to nitrogen. Coke was eliminated through a step-by-step process in which aromatic cycles were subsequently removed. This explains why for MOR, coke removal is observed, yet without recovery of the microporous volume (Scheme 2).

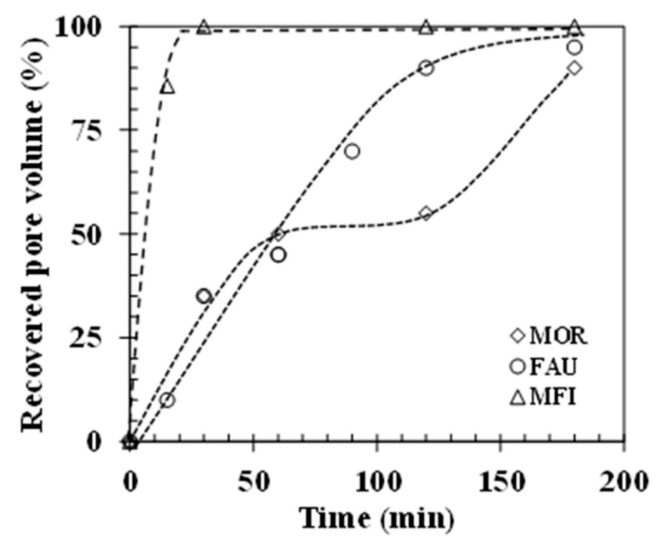

Figure 2. Percentage of microporous volume regenerated on MOR $(\diamond)$, FAU $(\bigcirc)$ and MFI $(\Delta)$ zeolites as a function of regeneration time for $12 \mathrm{~W}$ at $293 \mathrm{~K}$.

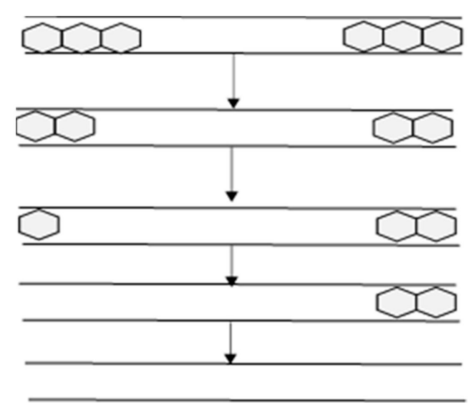

Scheme 2. Representation of the micropore volume recovery on MOR zeolite.

Figure 3 presents the fraction of regenerated Brønsted acid sites on the zeolite series as a function of the treatment time. For the MFI zeolite, all the acid sites are recovered within a few minutes, indicating their complete regeneration. For the MOR zeolite, the amount increases with time and reaches a plateau at $60 \%$ after $3 \mathrm{~h}$ of regeneration. Indeed, less than $2 \mathrm{wt} . \%$ of coke is enough to block the access of pyridine to $40 \%$ of the Brønsted acid sites. This explains why MOR is more difficult to regenerate compared to MFI. For the FAU, the amount of regenerated BAS increases proportionally with time and even exceeds the initial acidity of the zeolite, despite the presence of residual carbon. 


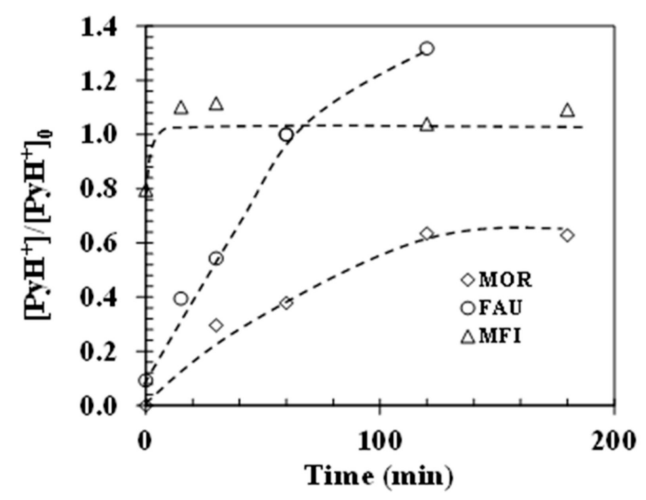

Figure 3. Fraction of Brønsted acid sites regenerated on MOR $(\diamond), F A U(\bigcirc)$ and MFI $(\Delta)$ zeolites as a function of regeneration time for $12 \mathrm{~W}$ at $293 \mathrm{~K}$.

This finding can be rationalized by the presence of carboxylic acid groups that result from coke oxidation that can protonate pyridine. Indeed, for the FAU zeolite, the coke removal leads to the decrease of the bands characteristics of coke precursor molecules (circa $1450 \mathrm{~cm}^{-1}$ ) [34] and polyaromatic compounds $\left(1604 \mathrm{~cm}^{-1}\right.$ and $\left.1380 \mathrm{~cm}^{-1}\right)$ [35,36], as well as the apparition of new bands centered at 1785 and $1751 \mathrm{~cm}^{-1}$ (Figure 4). These two bands can be ascribed to the $\mathrm{C}=\mathrm{O}$ stretching vibrational mode, and more particularly to carboxylic acids and ketones. This indicates that coke is functionalized during NTP treatment. For the MFI zeolite, after 15 min of NTP treatment, the extinction of bands related to coke is concomitant with the appearance of the band characteristic for carboxylic acid. After $30 \mathrm{~min}$, almost all of these bands are no longer observed for MFI. For the MOR zeolite, the decrease of the coke bands does not result in a clear appearance of carboxylic acid bands, indicating that the oxidation mechanism occurring in such mono-dimensional channel systems is different to that observed in a three-dimensional system.

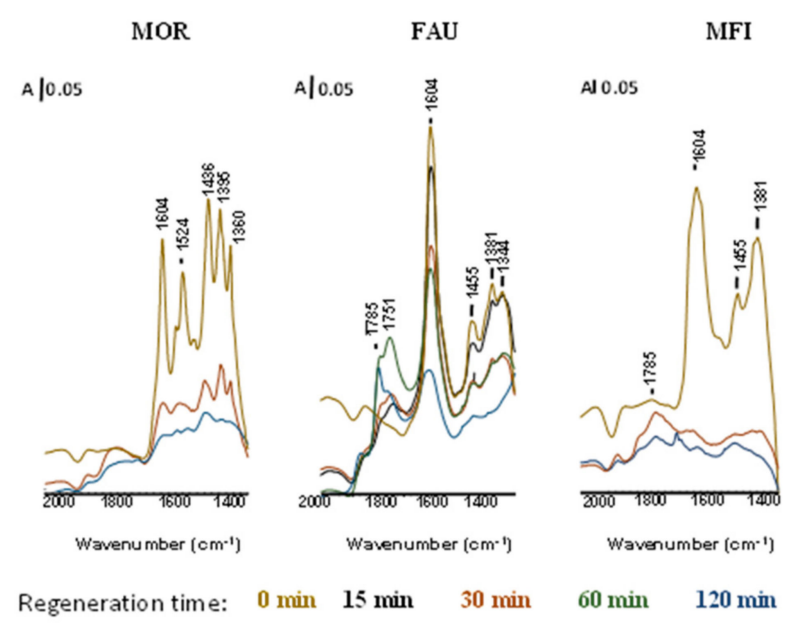

Figure 4. IR spectrum of MOR, FAU and MFI zeolites at different regeneration time for $12 \mathrm{~W}$ at $293 \mathrm{~K}$.

\section{Materials and Methods}

The commercial zeolites were supplied from Zeolyst (MFI, CBV 8014, FAU, CBV 720) and Süd Chemie (MOR). The coking of the protonic zeolites was carried out using a fixed bed reactor at $623 \mathrm{~K}$, under $0.1 \mathrm{MPa}$ of $\mathrm{P}_{\mathrm{C} 3 \mathrm{H} 6}$ and a GHSV of $6700 \mathrm{~h}^{-1}$. Before coking, zeolites were pressed, crushed and sieved $(0.2-0.4 \mathrm{~mm})$ and pretreated under $\mathrm{N}_{2}$ at $723 \mathrm{~K}$ for $12 \mathrm{~h}$.

Textural properties determined by sorption measurements of nitrogen at $77 \mathrm{~K}$ carried out with a Micromeritics ASAP 2000 gas adsorption analyzer. The fresh zeolites were pretreated under vacuum at $573 \mathrm{~K}$ for $15 \mathrm{~h}$, while the coked ones were outgassed at $423 \mathrm{~K}$ for $1 \mathrm{~h}$ in order to avoid coke elimination. The microporous volumes $\left(\mathrm{V}_{\text {micro }}\right)$ were calculated by applying by Harkins-Jurathe $\mathrm{t}$-plot reference 
isotherm. Total pore volume was determined at the relative pressure of 0.9 ; the mesoporous volume $\left(\mathrm{V}_{\text {meso }}\right)$ was calculated by subtracting microporous volume formtotal pore volume.

Fourier transformed Infrared spectra (FT-IR) of samples that were chemisorbed with pyridine were recorded using a Nicolet Magna 550-FT-IR spectrometer (with $2 \mathrm{~cm}^{-1}$ optical resolution). Zeolites were firstly pressed into self-supporting wafers $(1.6 \mathrm{~cm}, \approx 20 \mathrm{mg}$ ) and pretreated at $723 \mathrm{~K}$ (with a heating rate of $1.5 \mathrm{~K} \mathrm{~min}^{-1}$ for $5 \mathrm{~h}$ under a reduced pressure). Coked samples were outgassed at $363 \mathrm{~K}$ for $1 \mathrm{~h}$ and $423 \mathrm{~K}$ for $1 \mathrm{~h}$. Followed by pyridine adsorption at $423 \mathrm{~K}$. After establishing equilibrium pressure of $133 \mathrm{~Pa}$, the cell was evacuated at $623 \mathrm{~K}$ to remove physisorbed species. Quantification of pyridine on Brønsted and Lewis sites was determined from $1545 \mathrm{~cm}^{-1}\left(\varepsilon 1545=1.13 \mathrm{~cm} \mathrm{~mol}^{-1}\right)$ and $1454 \mathrm{~cm}^{-1}(\varepsilon 1454=1.28)$ [37].

The temperature of coke oxidation $\left(\mathrm{T}_{\mathrm{ox}}\right)$ was determined using a SDT Q600 TA thermogravimetric analyzer using a $100 \mathrm{~mL} / \mathrm{min}$ air flow and heating up to $1173 \mathrm{~K}$. The amount of carbon and hydrogen were measured using a C.E. Instruments NA2100 PROTEIN elementary analyzer.

External coke $\left(\mathrm{C}_{\text {external }}\right)$ was extracted through washing spent catalysts with methylene chloride $\left(\mathrm{CH}_{2} \mathrm{Cl}_{2}\right)$ at $313 \mathrm{~K}$ and $10 \mathrm{MPa}$ nitrogen pressure for $10 \mathrm{~min}$ on a Dionex ASE 350. Coke was further was recovered form samples after digestion using hydrofluoric acid (51 vol. \%) at $298 \mathrm{~K}$ for $20 \mathrm{~min}$. The soluble coke fraction leaves no residue in $\mathrm{CH}_{2} \mathrm{Cl}_{2}$, while $\mathrm{C}_{\text {insoluble }}$ features black particles, which were recovered through filtration. The $\mathrm{C}_{\text {soluble }}$ fraction was analyzed and quantified by GC-MS and GC-FID after $\mathrm{CH}_{2} \mathrm{Cl}_{2}$ evaporation.

The cylindrical fixed bed dielectric barrier reactor was set up by two co-axial electrodes that were separated by a Pyrex tube (i.d. $=9.5 \mathrm{~mm}$, thickness $=0.5 \mathrm{~mm}$ ) as a dielectric barrier [10]. The outer electrode was wrapped around the glass tube (copper sheet of $20 \mathrm{~mm}$ length). The inner electrode consisted of a stainless inox rod (diameter $=1.3 \mathrm{~mm}$ ). Electrodes were connected using a high voltage (HV) bi-polar pulse generator (A2E-Enertronic, Paris, France).

The energy dissipated per pulse (Er) in the reactor was determined using the following correlation: $E_{r}=\int_{0}^{\tau} I(t) \times V(t) d t$, where $\tau$ is the bipolar pulse duration. The instantaneous voltage current $\mathrm{I}(\mathrm{t})$ and $\mathrm{V}(\mathrm{t})$ were measured by an Oscilloscope (Lecroy LT374L, $500 \mathrm{MHz}, 4 \mathrm{GS} / \mathrm{s}$ ) by using an inductive probe for the current (Stangenes Industries $60 \mathrm{MHz}$ ) and a high voltage probe (Tektronix P6015A, $75 \mathrm{MHz}$ ). Input power was fixed at $12 \mathrm{~W}$, corresponding to a frequency of $2200 \mathrm{~Hz}$ and a voltage of $10 \mathrm{kV}$. The temperature within the catalytic bed was determined using an optic fiber, which did not exceed $373 \mathrm{~K}$.

The gas feed was composed of $20 \mathrm{vol} \% \mathrm{O}_{2}$ in He. The GHSV was set at $6000 \mathrm{~h}^{-1}$, calculated at $293 \mathrm{~K}$ and $1 \mathrm{~atm}$. The composition of the gas flow at the reactor outlet was achieved using an on-line gas chromatographic analysis (Micro GC Varian CP 4900, $\mathrm{CO}_{x}$ column), which was equipped with a TCD detector.

\section{Conclusions}

The regeneration of a series of coked zeolites, including FAU, MOR and MFI, was investigated using a DBD plasma reactor. It was observed that the efficiency of coke oxidation by non-thermal plasma is very sensitive to both the coke nature and its toxicity. Coke precursors constituted of one or two aromatic rings are totally oxidized into $\mathrm{CO}_{2}$, while polyaromatic molecules yield organic volatile compounds. For MFI and FAU zeolites with three-dimensional 10 or 12 membered ring channel systems, coke toxicity is moderate. As a consequence, the short-lived oxygenated species generated by NTP can access and oxidize coke molecules. The kinetic oxidation rate is independent of the size of the pore aperture. As the partial kinetic order for coke is zero the time required to regenerate the zeolite (recovery of the initial micropore volume and Brønsted acidity) is dependent on the initial coke content. For MOR, featuring a one-dimensional 12 membered ring channel system, coke toxicity is very high, as one coke molecule located on the pore mouth blocks the access to the entire pore channel. As a result, coke removal rate is slower and even prolonged regeneration times do not permit for full recovery of microporosity and acidity. Compared to classical calcination for the regeneration of spent catalysts, non-thermal plasma reveals to be a cleaner technology. 
Supplementary Materials: The following are available online at http://www.mdpi.com/2073-4344/9/12/985/s1. Structures of FAU, MOR and MFI zeolites and their isotherms of nitrogen adsorption at 77 K. Figure S1: $\mathrm{N}_{2}$ adsorption (solid symbols) and desorption (open symbols) isotherms at $77 \mathrm{~K}$ of FAU, MOR and MFI zeolites.

Author Contributions: Data curation, A.A.; Writing—review and editing, C.B.-D. and A.S.; writing-original and Supervision, L.P.

Funding: This research was funded by PAUSE.

Acknowledgments: Amir Astafan thanks the Programme PAUSE and the University of Poitiers for their financial supports. The authors acknowledge financial support from the European Union (ERDF) and the "Région Nouvelle Aquitaine".

Conflicts of Interest: The authors declare no conflict of interest.

\section{References}

1. Guisnet, M.; Ramoa Ribeiro, F. Deactivation and regeneration of solid catalysts. In Deactivation and Regeneration of Zeolite Catalysts; Imperial College Press: London, UK, 2011; pp. 3-18.

2. Dejaifve, P.; Auroux, A.; Gravelle, P.C.; Védrine, J.C.; Gabelica, Z.; Derouane, E.J. Methanol conversion on acidic ZSM-5, offretite, and mordenite zeolites: A comparative study of the formation and stability of coke deposits. J. Catal. 1981, 70, 123-136. [CrossRef]

3. Schulz, H.; Siwei, Z.; Baumgartner, W. Coke forming reactions during methanol conversion on zeolite catalysts. Stud. Surf. Sci. Catal. 1987, 34, 479-492.

4. Sexton, B.A.; Hughes, A.E.; Bibby, D.M. An XPS study of coke distribution on ZSM-5. J. Catal. 1988, 109, 126-131. [CrossRef]

5. Meinhold, R.H.; Bibby, D.M. ${ }^{13}$ C CPMAS n.m.r. study of coke formation on HZSM-5. Zeolites 1990, 10, 121-130. [CrossRef]

6. Magnoux, P.; Cerqueira, H.S.; Guisnet, M. Evolution of coke composition during ageing under nitrogen. Appl. Catal. A Gen. 2002, 235, 93-99. [CrossRef]

7. Aguayo, T.; Gayubo, A.G.; Erena, J.; Atutxa, A.; Bilbao, J. Coke Aging and Its Incidence on Catalyst Regeneration. Ind. Eng. Chem. Res. 2003, 42, 3914-3921. [CrossRef]

8. Ortega, J.M.; Gayubo, A.G.; Aguyo, A.T.; Benito, P.L. Role of coke characteristics in the regeneration of a catalyst for the MTG process. Ind. Eng. Chem. Res. 1997, 36, 60-66. [CrossRef]

9. Pinard, L.; Bichon, B.; Popov, A.; Lemberton, J.L.; Canaff, C.; Maugé, F.; Bazin, P.; Falabella, E.S.; Magnoux, P. Identification of the carbonaceous compounds present on a deactivated cobalt based Fischer-Trospch catalyst resistant to "rejuvenation treatment". Appl. Catal. A Gen. 2011, 406, 73-80. [CrossRef]

10. Dmitriadis, V.D.; Lappas, A.A.; Vasalos, I.A. Kinetics of combustion of carbon in carbonaceous deposits on zeolite catalysts for fluid catalytic cracking units (FCCU). Comparison between Pt and non Pt-containing catalysts. Fuel 1998, 77, 1377-1383. [CrossRef]

11. Le Minh, C.; Jones, R.A.; Craven, I.E.; Brown, T.C. Temperature-Programmed oxidation of coke deposited on cracking catalysts: Combustion mechanism dependence. Energy Fuels 1997, 11, 463-469. [CrossRef]

12. Marcilla, A.; Beltran, M.I.; Navarro, R.J. Anal Effect of regeneration temperature and time on the activity of HUSY and HZSM5 zeolites during the catalytic pyrolysis of polyethylene. J. Anal. Appl. Pyrolysis 2005, 74, 361-369. [CrossRef]

13. Villegas, J.I.; Kumar, N.; Heikkilä, T.; Lehto, V.P.; Salmia, T.; MurzinIsomerization, D.Y. Isomerization of $n$-butane to isobutane over Pt-modified Beta and ZSM-5 zeolite catalysts: Catalyst deactivation and regeneration. Chem. Eng. J. 2006, 120, 83-89. [CrossRef]

14. Kosinov, N.; Ferdy, J.A.; Coumans, G.; Uslamin, E.; Kapteijn, F.; Hensen, E.J.M. Selective Coke Combustion by Oxygen Pulsing During Mo/ZSM-5-Catalyzed Methane Dehydroaromatization. Chem. Int. Ed. 2016, 55, 1-6. [CrossRef] [PubMed]

15. Fernandes, V.J.; Araujo, A.S. Kinetic study of HY zeolite regeneration by thermogravimetry. Thermochim. Acta 1995, 255, 273-280. [CrossRef]

16. Magnoux, P.; Guisnet, M. Coking ageing and regeneration of zeolites: VI. comparison of the rates of coke oxidation of HY, H-mordenite and HZSM-5. Appl. Catal. 1988, 38, 341-352. [CrossRef]

17. Novakova, J.; Dolejsek, Z. A comment on the oxidation of coke deposited on zeolites. Zeolites 1990, 10, 189-192. [CrossRef] 
18. Jong, S.J.; Pradhan, A.R.; Wu, J.F.; Tsai, T.C.; Liu, S.B. On the regeneration of coked H-ZSM-5 catalysts. J. Catal. 1998, 174, 210-218. [CrossRef]

19. Hashimoto, K.; Masuada, T.; Mori, T. Kinetics of combustion of carbonaceous deposits on HZSM-5 zeolites. Chem. Eng. Sci. 1988, 43, 2275-2280. [CrossRef]

20. Bilbao, J.; Romero, A.; Arandes, J.M. Kinetic equation for the regeneration of a solid catalyst by coke-burning. Chem. Eng. Sci. 1983, 38, 1356-1360. [CrossRef]

21. Moljord, K.; Magnoux, P.; Guisnet, M. Evidence for a participation of zeolite acid sites in the coke removal through oxidative treatment. Catal. Lett. 1994, 25, 141-147. [CrossRef]

22. Stepanov, V.G.; Paukshtis, E.A.; Chesnokov, V.V. Mechanism of coking and regeneration of catalysts containing ZSM-5 zeolite. Stud. Surf. Sci. Catal. 2000, 130, 2969-2974.

23. Sen, H.; Shen, B.-X.; Liu, J.-C. Oxidative regeneration of deactivated binderless 5A molecular sieves for the adsorption-separation of normal hydrocarbons. Fuel Chem. Technol. 2009, 37, 734-739. [CrossRef]

24. Lakiss, L.; Ngoye, F.; Canaff, C.; Gilson, J.-P.; Laforge, S.; Qin, Z.; Tarighi, M.; Thomas, K.; Valtchev, V.; Vicente, A.; et al. On the remarkable resistance to coke formation of nanometer-sized and hierarchical MFI zeolites during ethanol to hydrocarbons transformation. J. Catal. 2015, 328, 165-172. [CrossRef]

25. Astafan, A.; Benghalem, M.A.; Michelin, L.; Patarin, J.; Pinard, L.; Daou, T.J. Synthesis of hierarchical ZSM-48 nano-zeolites. N. J. Chem. 2018, 42, 4457-4464. [CrossRef]

26. Astafan, A.; Benghalem, M.A.; Patarin, J.; Pouilloux, Y.; Bats, N.; Bouchy, C.; Daou, T.J.; Pinard, P. Particular properties of the coke formed on nano-sponge ${ }^{*} \mathrm{BEA}$ zeolite during ethanol-to-hydrocarbons transformation. J. Catal. 2016, 336, 1-10. [CrossRef]

27. Qin, Z.; Pinard, L.; Benghalem, M.A.; Daou, T.J.; Melinte, G.; Ersen, O.; Asahina, S.; Gilson, J.-P.; Valtchech, V. Preparation of Single-Crystal "House-of-Cards"-like ZSM-5 and Their Performance in Ethanol-to-Hydrocarbon Conversion. Chem. Mater. 2019, 31, 4639-4648. [CrossRef]

28. Jia, L.; Al Farouha, L.; Pinard, L.; Heden, S.; Comparot, J.-D.; Ben Tayeb, K.; Dufour, A.; Vezin, H.; Batiot-Dupeyrat, C. New routes for complete regeneration of coked zeolite. Appl. Catal. B Environ. 2017, 219, 82-91. [CrossRef]

29. Pinard, L.; Batiot-Dupeyrat, C. Method for Decontaminanting a Catalyst Conataminated with Carbon, Patent No. WO/2018/087505. 17 May 2018.

30. Pinard, L.; Ayoub, N.; Batiot-Dupeyrat, C. Regeneration of a Coked Zeolite via Nonthermal Plasma Process: A Parametric Study. Plasma Chem. Plasma Process. 2019, 39, 929-936. [CrossRef]

31. Astafan, A.; Batiot-Dupeyrat, C.; Pinard, L. Mechanism and Kinetic of Coke Oxidation by Nonthermal Plasma in Fixed-Bed Dielectric Barrier Reactor. J. Phys. Chem. C 2019, 123, 9168-9175. [CrossRef]

32. Chaouati, N.; Soualah, A.; Chater, M.; Tarighi, M.; Pinard, L. Mechanisms of coke growth on mordenite zeolite. J. Catal. 2016, 344, 354-364. [CrossRef]

33. Chaouati, N.; Soualah, A.; Chater, M.; Pinard, L. Beneficial changes in coke properties with alkaline treatment on aluminum-rich mordenite. J. Catal. 2017, 353, 28-36. [CrossRef]

34. Yao, X.; Zhang, J.; Liang, X.; Long, C. Plasma-catalytic removal of toluene over the supported manganese oxides in DBD reactor: Effect of the structure of zeolites support. Chemosphere 2018, 208, 922-930. [CrossRef] [PubMed]

35. Cerqueira, H.S.; Rabeharitsara, A.; Ayrault, P.; Datka, J.; Magnoux, P.; Guisnet, M. Mechanisms of coke growth on mordenite zeolite. Stud. Surf. Sci. Catal. 2001, 139, 29-36.

36. Cerqueira, H.S.; Ayrault, P.; Datka, J.; Guisnet, M. Influence of coke on the acid properties of a USHY zeolite. Microporous Mesoporous Mater. 2000, 38, 197-205. [CrossRef]

37. Miranda, C.; Urresta, J.; Cruchade, H.; Tran, A.; Benghalem, M.; Astafan, A.; Gaudin, P.; Daou, T.J.; Ramirez, A.; Pouilloux, Y.; et al. Exploring the impact of zeolite porous voids in liquid phase reactions: The case of glycerol etherification by tert-butyl alcohol. J. Catal. 2018, 365, 249-260. [CrossRef]

(C) 2019 by the authors. Licensee MDPI, Basel, Switzerland. This article is an open access article distributed under the terms and conditions of the Creative Commons Attribution (CC BY) license (http://creativecommons.org/licenses/by/4.0/). 